\title{
Research of LED assembly line Modeling and Optimization based on the Petri Net
}

 \\ 1. The Key Laboratory of Intelligent Manufacturing and Robotics, School of Mechatronic \\ Engineering and Automation, Shanghai University, Mailbox 232, No. 149 yanchang Road, \\ Shanghai, China, 200072 \\ 2. Department of Mechanical Engineering, University of Michigan, Ann Arbor, MI, 48105, U.S. \\ auweiminghu@163.com, bsufeimasohxm@163.com, corresponding author '672914707@qq.com, \\ dyutao@shu.edu.cn exinrshi@umich.edu
}

Keywords: Fuzzy Hierarchical Petri Net, assembly line, model optimization, fault diagnosis

\begin{abstract}
In order to reduce the design flaw and improve the productivity, the model of LED bulb assembly line based on the Fuzzy Hierarchical Petri Net is proposed. The process of LED bulb assembly line is given, and the hierarchical modeling based on FHPN is described. The model of LED bulb assembly line includes three layers and each layer is defined. Through the analysis of the time performance of the model based on FHPN, the optimization model of the LED bulb assembly line is put forward. The experimental result shows that the takt time of the optimization model decreases by $13.3 \%$ compared with that of the original model, which increases the production efficiency rate.
\end{abstract}

\section{Introduction}

With the wide use of LED light source, automation assembly lines are gradually adopted to assemble the LED bulb in order to solve the problems of low production efficiency and mass instability in the process of manual or semi-automatic assembly[1]. However, automation assembly line has some features, including various devices, numerous parts, integration of multiple functions. Therefore, modeling and simulation of assembly line is applied to reduce the design flaws, improve the productivity and utilization of equipments, reduce the production time and improve the return on investment.

In this paper, LED bulb assembly process is analyzed at first. Then, the model of LED bulb assembly line based on Fuzzy Hierarchical Petri Net is proposed. The model is divided into three layers, including the production layer, device layer, fault layer. The relationship between each layer is established. Next, the model is imported into the visual environment for simulation. Finally, according to the performance analysis of LED bulb assembly line based on Fuzzy Hierarchical Petri Net, the model is optimized.

\section{Fuzzy Hierarchical Petri Net}

Fuzzy Petri Net is an extension of basic Petri Net. It is different from basic Petri Net in that a token incorporated with a place is associated with a real value between 0 and 1 , a transition is associated with a CF between 0 and 1, and enabling and firing rules of a transition are also updated at the same time[2-4]. Fuzzy Petri Net can be used to depict fuzzy generating rules that can be taken as rules of fuzzy relationships between two propositions. Hierarchical Petri Net merges the similar Place in Petri Net from bottom to up in order to simplify the model. The Fuzzy Hierarchical Petri Net (FHPN) combines these advantages[5-7].

Definition of Fuzzy Hierarchical Petri Net $S_{F H P N}$ can be described with nine members, as follows:

$$
S_{\text {FHPN }}=(L, P, T, I, O, M, \lambda, W, U) \text {. }
$$


(1) $\mathrm{L}$ is a set of pages. A page is in fact an extension of a HFPN subnet;

(2) $P=\left\{p_{1}, \ldots \ldots, p_{n}\right\}$ is finite set of Place;

(3) $T=\left\{t_{1}, \ldots \ldots, t_{n}\right\}$ is finite set of Transition;

(4) $I: P \times T \rightarrow N$ is input function; it defines the repetition of connection or set of weight from $P$ to T. $N=\{0,1, \ldots \ldots\}$ is set of nonnegative integers here.

(5) $O: T \times P \rightarrow N$ is output function; it defines repetition of directed arc or set of weight from $T$ to $P$.

(6) $M: P \rightarrow[0,1]$ denotes a mapping. Each node of the place $P_{i} \in P \quad(i=1,2 \mathrm{~L} n)$ has its own value $M\left(P_{i}\right)$;

(7) $\lambda=\left\{\lambda_{1}, \lambda_{2} \mathrm{~L} \mathrm{~L} \lambda_{n}\right\}$ is threshold value of transition $t_{1}, \ldots \ldots, t_{n}$;

(8) $W=\left\{W_{1}, W_{2} \mathrm{~L} L W_{q}\right\}$ is a set of rule weights;

(9) $U=\left\{U_{1}, U_{2}, \mathrm{~L} \mathrm{~L} U_{n}\right\}$ is the certainty factor of transition $t_{1}, \ldots \ldots, t_{n}$, which is determined by historical records.

\section{The Process of LED Bulb Assembly Line}

LED bulb assembly line consists of three workstations: light source assembly workstation; power assembly workstations and product inspection workstation. Conveyor belts are used to achieve automatic connection between workstations. In order to enhance the degree of automation, nine automatic feeding devices around these workstations realize automatic feeding of all the parts (including screws, thermal conductivity silicone grease) of LED bulb. The assembly process contains 9 procedures, which is shown in Figure 1.

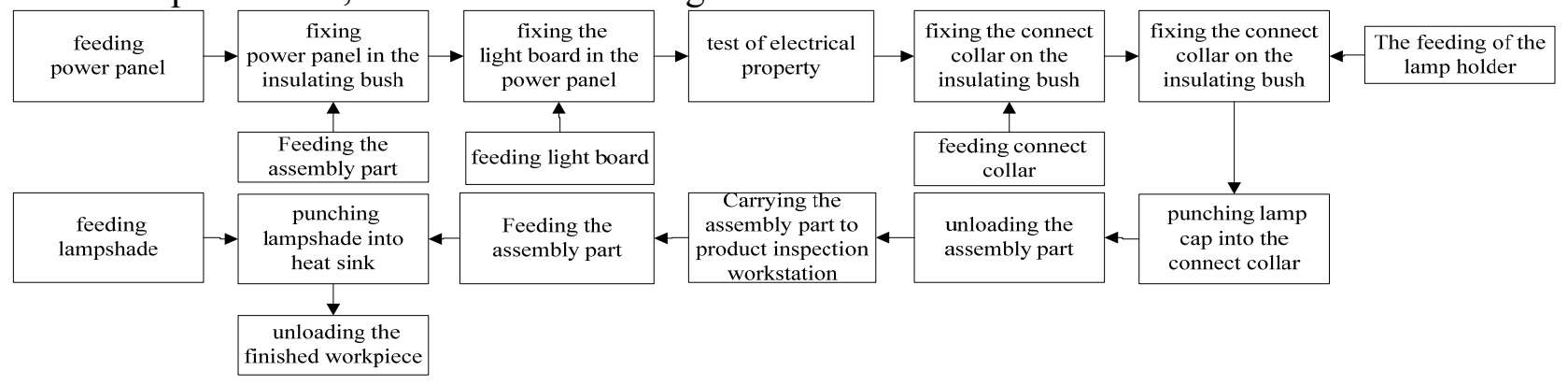

Figure 1 . The assembly process of LED bulb assembly line

\section{The Hierarchical Modelling of LED Bulb Assembly Line based on FHPN}

Take a process of the LED bulb assembly line which is shown in the Figure 1 as an example, a Fuzzy Hierarchical Petri Net model is established. The model of the assembly line includes 2 workstations, 9 procedures, 17 devices and 24 groups of faults.

Production layer model.

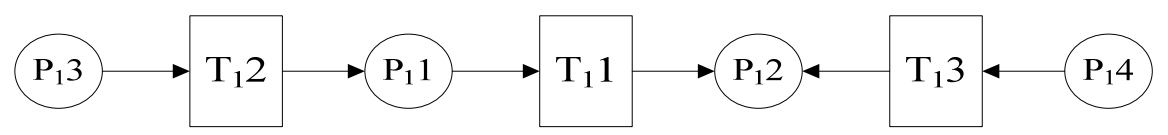

Figure 2. The model of production layer 
Table 1. The meanings of the places and transitions in the production layer

\begin{tabular}{|c|l|c|l|}
\hline Place & \multicolumn{1}{|c|}{ meaning of Place } & Transition & \multicolumn{1}{|c|}{ meaning of Transition } \\
\hline $\mathrm{P}_{1} 1$ & Assembly Place for power assembly workstation & $\mathrm{T}_{1} 1$ & $\begin{array}{l}\text { Parts arrive product inspection workstation } \\
\text { from power assembly workstation }\end{array}$ \\
\hline $\mathrm{P}_{1} 2$ & Test Place for product inspection workstation & $\mathrm{T}_{1} 2$ & Parts are fed to power assembly workstation \\
\hline $\mathrm{P}_{1} 3$ & Feeding Place for power assembly workstation & $\mathrm{T}_{1} 3$ & $\begin{array}{l}\text { Part are fed to product inspection } \\
\text { workstation }\end{array}$ \\
\hline $\mathrm{P}_{1} 4$ & Feeding Place for product inspection workstation & & \\
\hline
\end{tabular}

\section{Device layer model.}

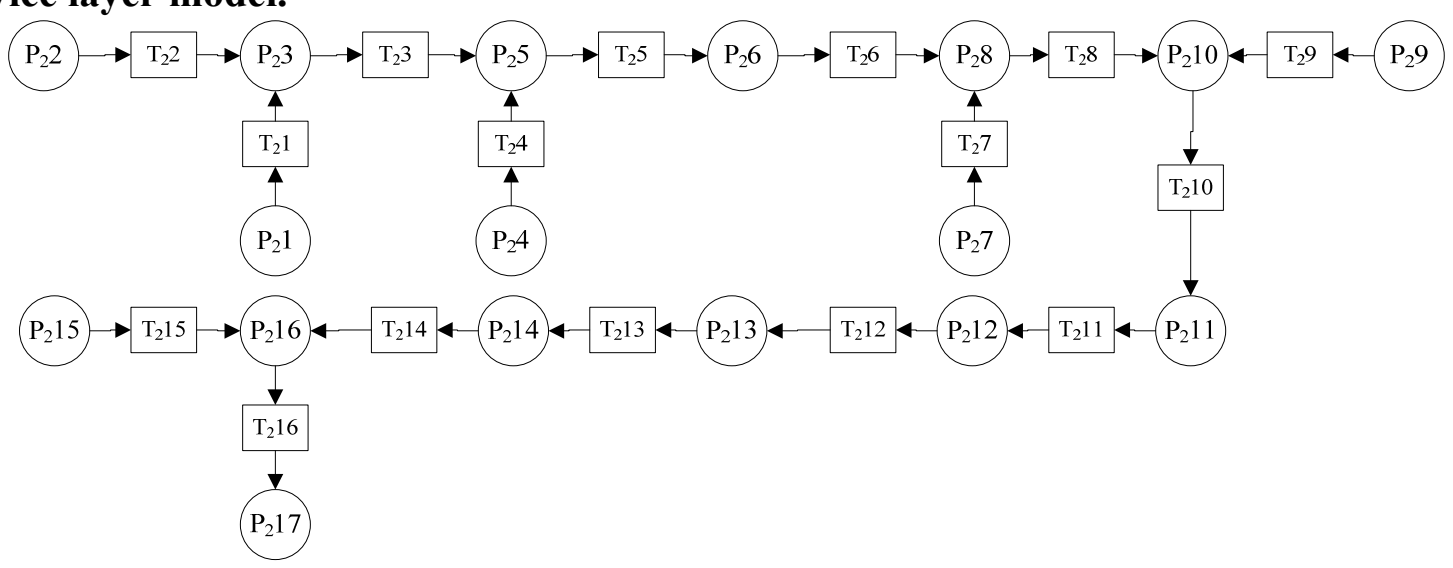

Figure 3. The model of device layer

Table 2. The meanings of the places and transitions in the production layer

\begin{tabular}{|c|c|c|c|}
\hline Place & meaning of Place & Transition & meaning of Transition \\
\hline $\mathrm{P}_{2} 1$ & $\begin{array}{l}\text { Robot loading place into power assembly } \\
\text { workstation }\end{array}$ & $\mathrm{T}_{2} 1$ & Robot loading finished \\
\hline $\mathrm{P}_{2} 2$ & Feeding place of power panel & $\mathrm{T}_{2} 2$ & Power panel feeding finished \\
\hline $\mathrm{P}_{2} 3$ & Robot assembly place of power panel & $\mathrm{T}_{2} 3$ & Robot loading finished \\
\hline $\mathrm{P}_{2} 4$ & Feeding place of light board & $\mathrm{T}_{2} 4$ & Light board feeding finished \\
\hline $\mathrm{P}_{2} 5$ & $\begin{array}{l}\text { Robot assembly place of the light board and power } \\
\text { panel }\end{array}$ & $\mathrm{T}_{2} 5$ & Robot assembly finished \\
\hline $\mathrm{P}_{2} 6$ & Test place of electrical property & $\mathrm{T}_{2} 6$ & Electrical property test finished \\
\hline $\mathrm{P}_{2} 7$ & Feeding place of connect collar & $\mathrm{T}_{2} 7$ & Connect collar feeding finished \\
\hline $\mathrm{P}_{2} 8$ & Robot assembly place of & $\mathrm{T}_{2} 8$ & Robot assembly finished \\
\hline $\mathrm{P}_{2} 9$ & Feeding place of lamp holder & $\mathrm{T}_{2} 9$ & Lamp holder feeding finished \\
\hline $\mathrm{P}_{2} 10$ & $\begin{array}{l}\text { Robot assembly place of fixing lamp holder on } \\
\text { insulating bush }\end{array}$ & $\mathrm{T}_{2} 10$ & Robot assembly finished \\
\hline $\mathrm{P}_{2} 11$ & Stamping cylinder place & $\mathrm{T}_{2} 11$ & Cylinder finished stamping \\
\hline $\mathrm{P}_{2} 12$ & $\begin{array}{l}\text { Robot unloading place from power assembly } \\
\text { workstation }\end{array}$ & $\mathrm{T}_{2} 12$ & Robot unloading finished \\
\hline $\mathrm{P}_{2} 13$ & $\begin{array}{l}\text { Conveyor belt place between power assembly } \\
\text { workstation and product inspection workstation }\end{array}$ & $\mathrm{T}_{2} 13$ & $\begin{array}{l}\text { Conveyor belt handling finished, workpiece } \\
\text { arrived product inspection workstation }\end{array}$ \\
\hline $\mathrm{P}_{2} 14$ & $\begin{array}{l}\text { Place of robot loading workpiece into product } \\
\text { inspection workstation }\end{array}$ & $\mathrm{T}_{2} 14$ & Robot loading finished \\
\hline $\mathrm{P}_{2} 15$ & Feeding place of lampshade & $\mathrm{T}_{2} 15$ & Lampshade feeding finished \\
\hline $\mathrm{P}_{2} 16$ & Lampshade assembly place & $\mathrm{T}_{2} 16$ & Lampshade assembly finished \\
\hline $\mathrm{P}_{2} 17$ & $\begin{array}{l}\text { Robot unloading place from the LED bulb } \\
\text { assembly line }\end{array}$ & & \\
\hline
\end{tabular}




\section{Fault layer model.}

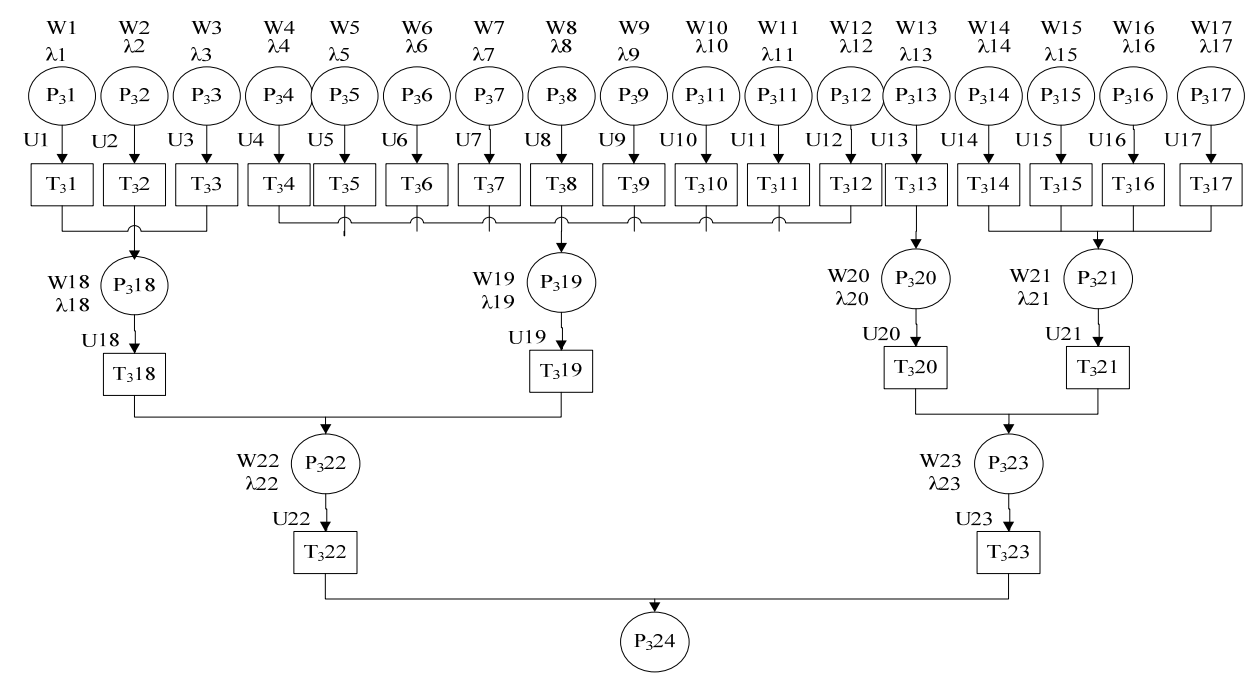

Figure 4. The model of fault layer

Table 3. The meanings of the places and transitions in the fault layer

\begin{tabular}{|c|c|c|c|}
\hline $\mathrm{P}_{3} 1$ & Feeding fault of power panel & $\mathrm{T}_{3} 1$ & Power panel feeding fault occurred \\
\hline $\mathrm{P}_{3} 2$ & Feeding fault of light board & $\mathrm{T}_{3} 2$ & Light board feeding fault occurred \\
\hline $\mathrm{P}_{3} 3$ & Feeding fault of connect collar & $\mathrm{T}_{3} 3$ & Connect collar feeding fault occurred \\
\hline $\mathrm{P}_{3} 4$ & $\begin{array}{l}\text { Feeding workpiece fault into power } \\
\text { assembly workstation }\end{array}$ & $\mathrm{T}_{3} 4$ & $\begin{array}{l}\text { Feeding workpiece fault into power assembly } \\
\text { workstation occurred }\end{array}$ \\
\hline $\mathrm{P}_{3} 5$ & $\begin{array}{l}\text { Robot assembly fault of fixing power panel } \\
\text { in insulating bush }\end{array}$ & $\mathrm{T}_{3} 5$ & $\begin{array}{l}\text { Robot assembly fault of fixing power panel in } \\
\text { insulating bush occurred }\end{array}$ \\
\hline $\mathrm{P}_{3} 6$ & $\begin{array}{l}\text { Robot assembly fault of fixing light board in } \\
\text { power panel }\end{array}$ & $\mathrm{T}_{3} 6$ & $\begin{array}{l}\text { Robot assembly fault of fixing light board in } \\
\text { power panel occurred }\end{array}$ \\
\hline $\mathrm{P}_{3} 7$ & Test fault of electrical property & $\mathrm{T}_{3} 7$ & Test fault of electrical property occurred \\
\hline $\mathrm{P}_{3} 8$ & $\begin{array}{l}\text { Robot assembly fault of fixing connect } \\
\text { collar on insulating bush }\end{array}$ & $\mathrm{T}_{3} 8$ & $\begin{array}{l}\text { Robot assembly fault of fixing connect collar } \\
\text { on insulating bush occurred }\end{array}$ \\
\hline $\mathrm{P}_{3} 9$ & $\begin{array}{l}\text { Assembly fault of fixing lamp holder on } \\
\text { insulating bush }\end{array}$ & $\mathrm{T}_{3} 9$ & $\begin{array}{l}\text { Assembly fault of fixing lamp holder on } \\
\text { insulating bush occurred }\end{array}$ \\
\hline $\mathrm{P}_{3} 10$ & $\begin{array}{l}\text { Assembly fault of punching lamp cap into } \\
\text { connect collar }\end{array}$ & $\mathrm{T}_{3} 10$ & $\begin{array}{l}\text { Assembly fault of punching lamp cap into } \\
\text { connect collar occurred }\end{array}$ \\
\hline $\mathrm{P}_{3} 11$ & $\begin{array}{l}\text { Robot unloading fault from power assembly } \\
\text { workstation }\end{array}$ & $\mathrm{T}_{3} 11$ & $\begin{array}{l}\text { Robot unloading fault from power assembly } \\
\text { workstation occurred }\end{array}$ \\
\hline $\mathrm{P}_{3} 12$ & $\begin{array}{l}\text { Fault of conveyor belt between power } \\
\text { assembly workstation and product }\end{array}$ & $\mathrm{T}_{3} 12$ & $\begin{array}{l}\text { Fault of conveyor belt between power } \\
\text { assembly workstation and product inspection }\end{array}$ \\
\hline $\mathrm{P}_{3} 13$ & Feeding fault of lamp holder & $\mathrm{T}_{3} 13$ & Feeding fault of lamp holder occurred \\
\hline $\mathrm{P}_{3} 14$ & $\begin{array}{l}\text { Fault of Robot loading workpiece into } \\
\text { product inspection workstation }\end{array}$ & $\mathrm{T}_{3} 14$ & $\begin{array}{l}\text { Fault of Robot loading workpiece into product } \\
\text { inspection workstation occurred }\end{array}$ \\
\hline $\mathrm{P}_{3} 15$ & Test fault of heat sink & $\mathrm{T}_{3} 15$ & Test fault of heat sink occurred \\
\hline $\mathrm{P}_{3} 16$ & Lampshade assembly fault & $\mathrm{T}_{3} 16$ & Lampshade assembly fault occurred \\
\hline $\mathrm{P}_{3} 17$ & $\begin{array}{l}\text { Robot unloading fault from the LED bulb } \\
\text { assembly line }\end{array}$ & $\mathrm{T}_{3} 17$ & $\begin{array}{l}\text { Robot unloading fault from the LED bulb } \\
\text { assembly line occurred }\end{array}$ \\
\hline $\mathrm{P}_{3} 18$ & $\begin{array}{l}\text { Feeding fault of power assembly } \\
\text { workstation }\end{array}$ & $\mathrm{T}_{3} 18$ & $\begin{array}{l}\text { Feeding fault of power assembly workstation } \\
\text { occurred }\end{array}$ \\
\hline $\mathrm{P}_{3} 19$ & $\begin{array}{l}\text { Assembly fault of power assembly } \\
\text { workstation }\end{array}$ & $\mathrm{T}_{3} 19$ & $\begin{array}{l}\text { Assembly fault of power assembly } \\
\text { workstation occurred }\end{array}$ \\
\hline $\mathrm{P}_{3} 20$ & $\begin{array}{l}\text { Feeding fault of product inspection } \\
\text { workstation }\end{array}$ & $\mathrm{T}_{3} 20$ & $\begin{array}{l}\text { Feeding fault of product inspection } \\
\text { workstation occurred }\end{array}$ \\
\hline $\mathrm{P}_{3} 21$ & $\begin{array}{l}\text { Assembly fault of product inspection } \\
\text { workstation }\end{array}$ & $\mathrm{T}_{3} 21$ & $\begin{array}{l}\text { Assembly fault of product inspection } \\
\text { workstation occurred }\end{array}$ \\
\hline $\mathrm{P}_{3} 22$ & Power assembly workstation fault & $\mathrm{T}_{3} 22$ & Power assembly workstation fault occurred \\
\hline $\mathrm{P}_{3} 23$ & Product inspection workstation fault & $\mathrm{T}_{3} 23$ & Product inspection workstation fault occurred \\
\hline $\mathrm{P}_{3} 24$ & Assembly line fault & & \\
\hline
\end{tabular}


Table 4 . The fuzzy rule of fault layer

\begin{tabular}{|c|c|c|c|c|c|c|}
\hline The fuzzy Rule & $\begin{array}{c}\text { Place of } \\
\text { Condition }\end{array}$ & $\begin{array}{c}\text { Transition of } \\
\text { activation }\end{array}$ & $\begin{array}{c}\text { Place of } \\
\text { Conclusion }\end{array}$ & $\mathrm{U}_{\mathrm{i}}$ & $\mathrm{W}_{\mathrm{i}}$ & $\lambda_{\mathrm{i}}$ \\
\hline $\mathrm{R}_{1}$ & $\mathrm{P}_{3} 1$ & $\mathrm{~T}_{3} 1$ & $\mathrm{P}_{3} 18$ & 0.96 & 0.15 & 0.8 \\
\hline $\mathrm{R}_{2}$ & $\mathrm{P}_{3} 2$ & $\mathrm{~T}_{3} 2$ & $\mathrm{P}_{3} 18$ & 0.95 & 0.32 & 0.8 \\
\hline $\mathrm{R}_{3}$ & $\mathrm{P}_{3} 3$ & $\mathrm{~T}_{3} 3$ & $\mathrm{P}_{3} 18$ & 0.96 & 0.23 & 0.8 \\
\hline $\mathrm{R}_{4}$ & $\mathrm{P}_{3} 4$ & $\mathrm{~T}_{3} 4$ & $\mathrm{P}_{3} 19$ & 0.96 & 0.10 & 0.8 \\
\hline $\mathrm{R}_{5}$ & $\mathrm{P}_{3} 5$ & $\mathrm{~T}_{3} 5$ & $\mathrm{P}_{3} 19$ & 0.96 & 0.12 & 0.8 \\
\hline $\mathrm{R}_{6}$ & $\mathrm{P}_{3} 6$ & $\mathrm{~T}_{3} 6$ & $\mathrm{P}_{3} 19$ & 0.98 & 0.11 & 0.8 \\
\hline $\mathrm{R}_{7}$ & $\mathrm{P}_{3} 7$ & $\mathrm{~T}_{3} 7$ & $\mathrm{P}_{3} 19$ & 0.96 & 0.12 & 0.8 \\
\hline $\mathrm{R}_{8}$ & $\mathrm{P}_{3} 8$ & $\mathrm{~T}_{3} 8$ & $\mathrm{P}_{3} 19$ & 0.97 & 0.13 & 0.8 \\
\hline $\mathrm{R}_{9}$ & $\mathrm{P}_{3} 9$ & $\mathrm{~T}_{3} 9$ & $\mathrm{P}_{3} 19$ & 0.96 & 0.12 & 0.8 \\
\hline $\mathrm{R}_{10}$ & $\mathrm{P}_{3} 10$ & $\mathrm{~T}_{3} 10$ & $\mathrm{P}_{3} 19$ & 0.97 & 0.16 & 0.8 \\
\hline $\mathrm{R}_{11}$ & $\mathrm{P}_{3} 11$ & $\mathrm{~T}_{3} 11$ & $\mathrm{P}_{3} 19$ & 0.96 & 0.11 & 0.8 \\
\hline $\mathrm{R}_{12}$ & $\mathrm{P}_{3} 12$ & $\mathrm{~T}_{3} 12$ & $\mathrm{P}_{3} 19$ & 0.98 & 0.13 & 0.8 \\
\hline $\mathrm{R}_{13}$ & $\mathrm{P}_{3} 13$ & $\mathrm{~T}_{3} 13$ & $\mathrm{P}_{3} 20$ & 0.97 & 1 & 0.8 \\
\hline $\mathrm{R}_{14}$ & $\mathrm{P}_{3} 14$ & $\mathrm{~T}_{3} 14$ & $\mathrm{P}_{3} 21$ & 0.95 & 0.26 & 0.8 \\
\hline $\mathrm{R}_{15}$ & $\mathrm{P}_{3} 15$ & $\mathrm{~T}_{3} 15$ & $\mathrm{P}_{3} 21$ & 0.96 & 0.23 & 0.8 \\
\hline $\mathrm{R}_{16}$ & $\mathrm{P}_{3} 16$ & $\mathrm{~T}_{3} 16$ & $\mathrm{P}_{3} 21$ & 0.95 & 0.23 & 0.8 \\
\hline $\mathrm{R}_{17}$ & $\mathrm{P}_{3} 17$ & $\mathrm{~T}_{3} 17$ & $\mathrm{P}_{3} 21$ & 0.96 & 0.28 & 0.8 \\
\hline $\mathrm{R}_{18}$ & $\mathrm{P}_{3} 18$ & $\mathrm{~T}_{3} 18$ & $\mathrm{P}_{3} 22$ & 0.98 & 0.55 & 0.8 \\
\hline $\mathrm{R}_{19}$ & $\mathrm{P}_{3} 19$ & $\mathrm{~T}_{3} 19$ & $\mathrm{P}_{3} 22$ & 0.96 & 0.45 & 0.8 \\
\hline $\mathrm{R}_{20}$ & $\mathrm{P}_{3} 20$ & $\mathrm{~T}_{3} 20$ & $\mathrm{P}_{3} 23$ & 0.98 & 0.30 & 0.8 \\
\hline $\mathrm{R}_{21}$ & $\mathrm{P}_{3} 21$ & $\mathrm{~T}_{3} 21$ & $\mathrm{P}_{3} 23$ & 0.96 & 0.70 & 0.8 \\
\hline $\mathrm{R}_{22}$ & $\mathrm{P}_{3} 22$ & $\mathrm{~T}_{3} 22$ & $\mathrm{P}_{3} 24$ & 0.97 & 0.35 & 0.8 \\
\hline $\mathrm{R}_{23}$ & $\mathrm{P}_{3} 23$ & $\mathrm{~T}_{3} 23$ & $\mathrm{P}_{3} 24$ & 0.96 & 0.25 & 0.8 \\
\hline & & & & & & \\
\hline
\end{tabular}

When a fault occurs, Backward Reasoning is used to diagnose faults. Backward Reasoning is the process of finding information through arc variables from the opposite direction based on the graphic entity of Fuzzy Hierarchical Petri Net. The following step is shown as follows:

(1) When the fault P324 give an alarm, the system starts searching the model of fault layer. Because of the fact that W22 is largest among W22and W23, power assembly workstation fault P322 needs to be searched firstly;

(2) In P322search process, the assembly fault of power assembly workstation P319 needs to be searched firstly and the rest may be deduced by analogy;

(3) If there is no error in the light source assembly workstation, the search path needs to be changed. The priority level of search path depends on the value of Wi.

\section{The optimization model of the LED bulb assembly line}

The main performance indexs of the LED bulb assembly line include the energy-consumption performance, the time performance and the utilization of semi-finished products. Because the efficiency of the LED bulb assembly line is decided by the takt time, a short takt time can greatly promote the productivity. Therefore, what is cared about in the optimization model is the time performance.

Due to the parallel process in LED bulb assembly line, the takt time of the assembly line, which is defined as $\mathrm{P}_{\text {Total }}$, should be the longest takt time among the places. According to the calculation results the takt time of $\mathrm{P}_{2} 11$ is 7.5 second which is the longest, so the takt time of the assembly line is 7.5 second.

In order to optimize the LED bulb assembly line, the place $\mathrm{P}_{2} 11$ should be optimized. The optimization model of device layer is shown in Figure 5 


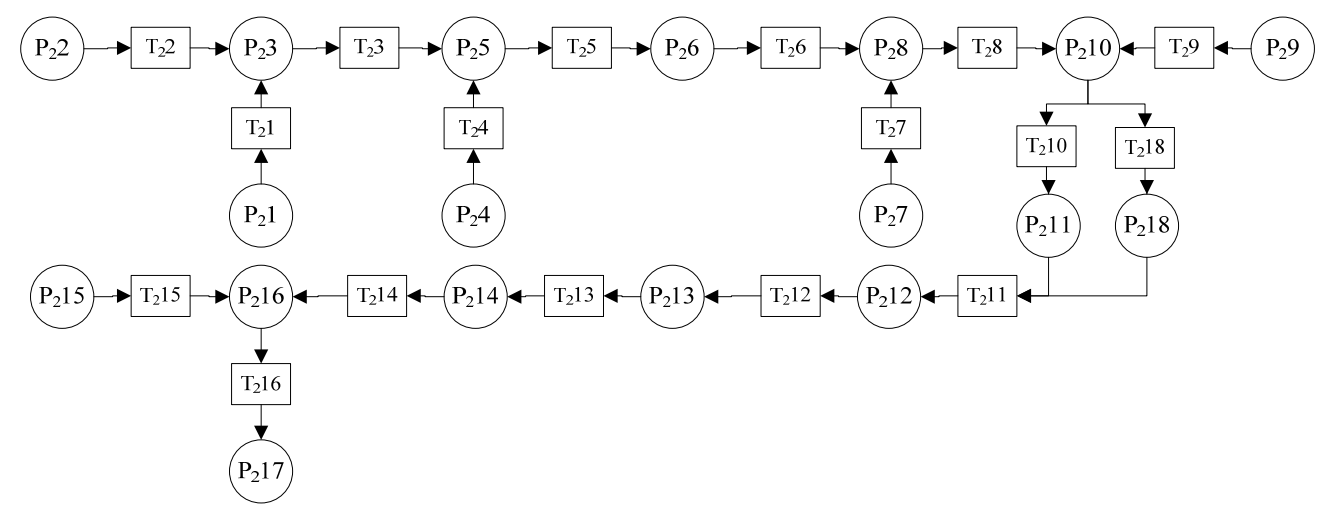

Figure 5. The optimization model of device layer

After the optimization, the takt time of the assembly line is decreased to 6.5 second. Compared with the original model, optimization model decreases takt time by $13.3 \%$, which shows the efficiency of optimization model.

\section{Conclusion}

Due to the complicated process in the LED bulb assembly line, Fuzzy Hierarchical Petri Net is applied to model and optimize the LED bulb assembly line. Three layers of the LED bulb assembly line, including production layer, device layer and fault layer are modeled. In order to solve the transition collision problem, the concept of $\mathrm{ARC}$ variables is proposed to improve the efficiency and accuracy of simulation. Visual Components software is adopted to simulate and analyze the layout of LED bulb assembly line. Optimization strategy is given in order to decrease the takt time of assembly line. Simulation results demonstrate the availability of LED bulb assembly line optimization model.

\section{Reference}

[1] Mogi K, Fujii T. A novel assembly technique with semi-automatic alignment for PDMS substrates[J]. Lab Chip, 2013, 13(6): 1044-1047.

[2] Li Yanfu, Zio Enrico, Lin Yanhui. A Multistate Physics Model of Component Degradation Based on Stochastic Petri Nets and Simulation[J]. IEEE Transactions on Reliability, 2012, 61(4):921-931

[3] Lefebvre Dimitri. About the stochastic and continuous Petri nets equivalence in the long run[J]. Nonlinear Analysis-Hybrid Systems, 2011, 5(3):394-406

[4] Dong Haiying, Li Xiaonan. Fault diagnosis for substations with redundant protection based on fuzzy Petri net[J]. Automation of Electric Power Systems, 2014, 38(4):98-103

[5] Hongjun Pan, Jigui Sun. Complex knowledge system modeling based on Hierarchical Fuzzy Petri Net[J]. 2007 IEEE/WIC/ACM International Conferences on Web Intelligence and Intelligent Agent Technology, 31-34.

[6] Xie Hongtao, Tong Xiaoyang. A method of synthetical fault diagnosis for power system based on fuzzy hierarchical Petri net[J]. Power System Technology, 2012, 36(1): 245-252

[7] Milinkovic Sanjin, Markovic Milan, Veskovic Slako. A fuzzy Petri net model to estimate train delays[J]. Simulation modeling practice and theory, 2013, 33, S1:144-157. 